УДК 343.226

О.М. ІГНАТОВ, канд. юрид. наук, ст. наук. співр., Кримський юридичний інститут Одеського державного університету внутрішніх справ

\section{НАСИЛЬСТВО ЯК СПОСІБ ВЧИНЕННЯ ЗЛОЧИНУ: ПОНЯТТЯ ТА СУТНІСТЬ}

Ключові слова: насильство, спосіб вчинення, ознаки, злочин

Будь-який злочин має зовнішнє вираження, що характеризується суспільно небезпечним діянням (дією чи бездіяльністю), суспільно небезпечними наслідками, причинним зв'язком між діянням і суспільно небезпечними наслідками, місцем, часом, обстановкою, способом, а також засобами вчинення злочину. Немає жодного злочину без властивого йому способу його вчинення, який являє собою форму прояву злочинного діяння та, відповідно, тісно пов'язаний з наслідком [1, c.182]. У теорії кримінального права під способом вчинення злочину розуміється форма прояву злочинної дії або бездіяльності (метод, прийом чи сукупність засобів, що використовуються для вчинення злочину) [2, с.105].

Проблеми способу вчинення злочину досліджували як вітчизняні, так і зарубіжні вчені: В.Н. Кудрявцев, В.О. Навроцький, М.I. Панов, Н.П. Пономарьова, Р.Д. Шарапов та ін. Однак, серед вчених на сьогодні не існує єдності поглядів навіть щодо зміст самого терміну способу вчинення злочину. Чимало питань виникає й щодо кримінальноправової сутності насильства як способу вчинення злочину. Метою даної статті є вирішення питання що слід розуміти під насильством, як кримінально-правовою категорією і які ознаки йому притаманні як способу вчинення злочину. Ії новизна полягає у наданому понятті та визначених ознаках насильства як способу вчинення злочину.

Насильство є способом вчинення значної кількості злочинів, передбачених Кримінальним кодексом України: від «класичних» злочинів проти життя та здоров'я (умисне вбивство, умисні тілесні ушкодження різного ступеня тяжкості, доведення до самогубства, побої та мордування, катування, погроза вбивством) до злочинів, передбачених іншими розділами Кримінального кодексу. Спосіб, властивий будь-якій вольовій поведінці людини, тому іманентний злочину як явищу реальної дійсності. Він наявний завжди, незалежно від того, чи зазначено його в законі, чи ні [3, с.6-7]. Кримінальний закон містить пряму вказівку на насильницький спосіб вчинення злочину (коли саме певний спосіб вчинення надає діянню характер суспільно небезпечного чи дозволяє відмежовувати його від інших діянь), або розуміння такого способу вчинення злочину випливає зі змісту самої кримінально-правової норми (при можливості вчинення злочину різними способами тощо). Насильницький спосіб вчинення злочину $є$ умовою диференціації кримінальної відповідальності у тому числі в межах одного і того ж складу злочину.

Законодавець при конструюванні насильницьких складів як прямо застосовує термін «насильство», «фізичне насильство», «психічне насильство», «насильницькі дії», так й інші загальні терміни («завдання удару», «мордування», «катування», «погроза», «примус», «напад», «знущання», «глумління», «тероризування» та ін.), а також терміни, що характеризують наслідки злочинного діяння («заподіяння смерті», «тілесне ушкодження», «особлива жорстокість» «особливе мучення», «фізичне страждання», «приниження гідності» та ін.). Крім того, для вираження насильницького способу вчинення злочину законодавець при формулюванні диспозиції відповідних норм використовує словосполучення на кшталт: «шляхом», «способом», «з використанням», «поєднане із», «мають характер», «із застосуванням», «що супроводжується» та ін. Однак, використовуючи термін «насильство», законодавець не дає його тлумачення, а інші зазначені терміни доволі часто використовує досить непослідовно, допускаючи різне їх тлумачення, 
або розкриваючи зміст одного терміну через інші, не розкриваючи при цьому зміст останніх. Типовий приклад такої законодавчої «техніки» - ст.126 КК України, у якій «побої», відповідно до ч.1, визначені законодавцем як «умисне завдання удару, побоїв (виокремлено мною - O.I.) або вчинення інших насильницьких дій, які завдали фізичного болю і не спричинили тілесних ушкоджень», а «мордування» відповідно до ч.2 визначене як «ті самі дії, що мають характер мордування (виокремлено мною - O.I.)».

3 огляду на те, що загальною ознакою, яка поєднує всі злочини в групу насильницьких, $\epsilon$ насильство над людиною, саме пов'язаність злочину з насильством, що застосовується при їхньому вчиненні, служить підставою віднесення злочинного діяння до групи насильницьких. Незважаючи на те, яке місце в механізмі вчинення злочину посідає насильство, воно є способом або метою злочинного діяння (вчинення злочинів, в яких саме спричинення фізичних чи психічних страждань жертві $\epsilon$ ціллю злочинця, неможливе ненасильницьким способом). Тому, законодавче закріплення поняття «насильство» (та законодавче закріплення змісту відповідних суміжних термінів) дозволить не лише уникнути помилок та свавілля при кваліфікації відповідних діянь, але й буде сприяти адекватній оцінці стану насильницької злочинності у нашому суспільстві відповідно 3 криміногенними реаліями часу. Як слушно зауважує I.M. Даньшин, «предметне, однакове поняття насильницької злочинності необхідно i для упорядкування поточного статистичного обліку, що у даний час далеко не досконалий, тому що він, як правило ведеться по главах Кримінального кодексу, по лінії різних підрозділів Міністерства внутрішніх справ і інших відомств і містить найчастіше поверхневу оперативну інформацію» [4, с. 63].

3 урахуванням зазначеного виникає питання, що слід розуміти під насильством, як кримінально-правовою категорією, і які ознаки йому притаманні як способу вчинення злочину.
Насильство $\epsilon$ крайньою формою, найбільш гострим і небезпечним проявом агресії $[5$, c.7; 6, с.24-26]. Аналіз різноманітних існуючих підходів до поняття насильства дозволяє визначити найбільш істотні його ознаки: 1) насильство здійснюється проти або поза волею потерпілого; 2) насильство пов язане з фізичним та/або психічним впливом на потерпілого; 3 ) застосування насильства може заподіяти шкоду потерпілому; 4) насильство може бути як засобом досягнення мети, так і метою.

Людина, як жива система, що являє собою нерозривну єдність фізичного та духовного, біологічного та соціального, може бути об'єктом найрізноманітніших способів впливу, які можна поділити на два види: фізичний та психічний. Такий підхід обумовлюється, насамперед, предметом впливу. Будь-які соціально значимі зусилля людини, що виявляються в його поведінці, мають предмет (об'єкт) своєї дії. Предмет людської діяльності індивідуалізує поведінку, є критерієм для розмежування людських вчинків. У літературі предмет насильницького впливу позначається як людина, організм людини тощо.

Існування людини представлене насамперед функціонуванням і розвитком живого організму найвищого порядку. У цьому складається біологічна сутність людини. Організм є біологічною основою людини, складає його матеріальну організацію. Заподіяння фізичної шкоди іншій людині досягається саме за допомогою насильницького впливу на його організм. Однак життя людини не зводиться лише до біологічної сторони іiі існування, але і неможливе поза нею. Як живий організм людина має особливий елемент психіку. Факт можливості психічно впливати на людину на певній відстані доводить, що границі індивіда не обмежуються фізичними розмірами його тіла, а включають у свою сферу також психічні явища [7, с.67]. Людина є єдністю двох взаємодіючих, але якісно різних підструктур - надбіологічної, яка забезпечує іiї соціальну сутність і біологічної, що $є$ передумовою її соціального існування 
[8, с.18]. Таким чином, психіка, хоча і являє собою одну з важливих функцій людського організму, проте не є фізіологічною. Особливий характер психічної сфери дає підстави вважати, що предметом фізичного насильства психіка, бути не може. Вона - предмет психічного насильства.

Під насильством слід розуміти енергетичний вплив на органи і тканини організму людини, їх фізіологічні функції, шляхом використання матеріальних факторів зовнішнього середовища (механічних, фізичних, хімічних і біологічних) та/або вплив на іiі психіку шляхом інформаційного впливу, що вчиняється всупереч або поза іiї волі, здатний заподіяти смерть, фізичну та/або психічну травму, а також обмежити свободу волевиявлення або дій людини [9].

Фізичне (енергетичне) насильство. Організм як біологічний субстрат людини складається $з$ окремих приватних структур - органів, тканин і тканинних елементів, об'єднаних у єдине ціле. Орган (більш-менш відособлена частина біологічної системи, що має самостійне функціональне значення в організмі) і тканина (сукупність кліток і міжклітинної речовини, об'єднана єдністю походження i функцій) $є$ найбільш загальними елементами структури організму людини i складають самостійний рівень організації живої матерії $[10$, с.6]. Таким чином, предметом впливу при фізичному насильстві $\epsilon$ структурні елементи організму людини (органи і тканини, їхні фізіологічні функції).

3 зовнішньої сторони фізичне насильство являє собою енергетичний вплив на органи i тканини (їх фізіологічні функції). Посягання на життєві властивості або функції організму людини полягає в енергетичному впливі на обмін речовин та енергії організму 3 навколишнім середовищем і в середині самого організму, на рух, контрольно-регуляторну функцію, що здійснюється нервовою системою та на інші фізіологічні функції. При енергетичному впливі процес шкідливих змін у предметі впливу носить чисто матеріальний характер і пов'язаний з переносом фізичної енергії (механічної, хімічної, теплової, ядерної та ін.).

Енергетичний вплив можливий шляхом використання винною особою матеріальних факторів зовнішнього середовища. До таких факторів відносяться: механічні, фізичні, хімічні, біологічні [11, с.14, 112, 138]. Відповідно цим факторам енергетичний вплив може бути класифікований на механічний (включає заподіяння фізичної шкоди внаслідок дії кінетичної енергії якого-небудь предмета), фізичний (включає дію високих і низьких температур, ушкодження електричним струмом, вплив різними видами променистої енергії, дія підвищеного і зниженого барометричного тиску), хімічний (досягається шляхом використання різних отрутних та сильнодіючих речовин у рідкому, твердому або газоподібному стані) і біологічний (полягає у зараженні різного роду патогенними мікробами, бактеріальними токсинами, що викликають хворобливі стани організму) [12, с.3745]. Дія зазначених факторів можлива за допомогою впливу на зовнішні покрови організму або внутрішні органи (їх функції).

Психічне (інформаційне) насильство. Підставою обгрунтування існування даного виду насильства $\epsilon$ психіка як особлива якість, властива людині, заснована на вищій нервовій діяльності і що виражається в здатності внутрішнього відображення дійсності у відчуттях, сприйняттях, почуттях, мисленні та волі. Будучи продуктом життєдіяльності суб'єкта, психіка, опосередковуючи іiі, виконує функцію орієнтації, керування нею. Вищим ступенем розвитку психіки є людська свідомість. 3 огляду на те, що одним 3 основних теоретичних принципів психології $є$ визнання обумовленості психічних явищ матеріальною дійсністю [13, с. 44], здійснення такого впливу можливо за допомогою різних факторів зовнішнього середовища i складає зміст психічного насильства.

Оскільки людина пов'язана 3 навколишнім середовищем численними інформаційними зв'язками, що здебільшого встановлюються на рівні підсвідомості людини, основ- 
ним елементом психічного насильства справедливо може вважатися інформація.

Спосіб впливу на психіку за допомогою інформації (інформаційний спосіб) зазвичай полягає у передачі сигнальної та значимої для адресата інформації, здатної вплинути на його психічний стан або психічні процеси [7, c.50]. Зазначений спосіб виражається у виді інформаційного процесу - повного циклу переробки інформації, включаючи трансляцію, сприйняття, перетворення і збереження сигналів [14, с.96-108]. Злочинне насильство нерідко здійснюється інформаційним шляхом за допомогою відкритого і «закодованого» сигналів. В останньому випадку сигнал, минаючи свідомість, безпосередньо впливає на підсвідомість, почуття і через уяву створює потрібні суб'єктові злочину психічні образи, котрими у подальшому керується об'єкт впливу у своїй поведінці [7, с.70].

Передача інформації може здійснюватися вербальним і невербальним шляхом. Тобто, здійснення передачі відповідної інформації можливо як у словесній формі (через форму (сварка, крик та ін.) та через зміст (погроза, лайка та ін.)), так й у формі відкритої та імпліцитної(схованої) поведінки: рухи і пози тіла, жести, мімічні вираження, постійне повторення моделей поведінки. Крім того, здійснення насильницького впливу на психіку людини можливо за допомогою образів (тексти, телеінформація, слайд-шоу), мови чисел, звукового впливу, сигналів запахів, гіпнозу та ін. Погоджуючись 3 концепцією лауреата Нобелевської премії $€$. Тоффлера про те, що сучасна історія людства вступає в свою «третю хвилю» або фазу, паролем або символом якої $є$ інформація [15, с. 255-56], складно переоцінити масштаби проблеми існування такого виду насильства, як психічне (інформаційне).

Психічне насильство може знаходити свій прояв у різноманітних формах впливу на психіку людину. Форми психічного насильства при цьому будуть залежати від навичок i життєвих установок особистості злочинця, а ступінь психогенного впливу - здебільшого від особистісних характеристик сприймаючого. Як свідчить практика, найпоширенішими формами психічного насильства $є$ : різні види погроз (вбивство, застосування фізичної сили, позбавлення волі, притягнення до кримінальної відповідальності, розповсюдження різних відомостей, пошкодження або знищення майна, підпал, позбавлення матеріального забезпечення і т.д.); примус; залякування; знущання; приниження; образа; шантаж тощо.

Говорячи про форми здійснення як психічного, так і фізичного насильства, слід враховувати постійний розвиток суспільства і технічного прогресу. Так, наприклад, виникають все більш нові способи впливу на функціональну діяльність мозку: шляхом впливу на несвідому функцію мозку; шляхом заморожування його окремих ділянок тощо [16, с.52].

У зв'язку $з$ тим, що людина $є$ єдністю двох взаємодіючих підструктур -біологічної і надбіологічної (психіки), фізичне насильство над людиною може мати як наслідки заподіяння психічних травм, так само, як наслідками впливу на психіку можуть бути порушення фізіологічних функцій організму i навіть смерть людини. Наприклад, такі фізичні насильницькі дії, як введення в кору головного мозку відповідних хімічних речовин, електронна стимуляція мозку можуть вкрай пагубне вплинути на психіку людини. Спричинення психічної травми можливо також через фізичний вплив безпосередньо на тіло людини (катування тощо).

На фізіологічному рівні причинно-наслідковий зв'язок між психічною травмою і функціональними розладами органів і тканин $\epsilon$ встановленим фактом. У результаті психічної травми можуть розвиватися паралічі, тремтіння, судорожні припадки, розлади слуху й мови, ряд інших розладів аналогічного характеру. Сильний переляк може викликати раптову зупинку болісно зміненого серця і смерть. При тривалому впливі психотравмуючої ситуації може наступити навіть стадія повного виснаження тканин, що здатне призвести до необоротних наслідків для 
організму [16, с.52].

Як енергетичний, так й інформаційний вплив можуть здійснюватися людиною: а) безпосередньо - шляхом особистого контакту (використовуючи можливості свого організму - фізичні або психічні. Використовуючи свої фізичні можливості, людина може використовувати м'язову силу свого тіла (наприклад, нанесення ударів, здавлювання шиї тощо), або може використовувати різні механізми, пристосування, інші засоби вчинення злочину (наприклад, удар ножем чи постріл зі зброї тощо) для посилення м'язової сили тіла; б) опосередковано - використовуючи поведінку іншої людини, яка не є суб'єктом злочину, інших живих істот; в) шляхом опосередкованого виконання - за допомогою усвідомленого і цілеспрямованого використання різних процесів і явищ зовнішнього світу.

Вчинення насильницького злочину можливе як шляхом дії, так й через бездіяльність, тобто насильницьких спосіб вчинення злочину може являти собою форму прояву злочинної дії або бездіяльності. Бездіяльність, як і дія, $\epsilon$ однією із форм поведінки, яка включена у систему суспільних відносин, i, відповідно, за певних умов може впливати на них [17, с.57-67]. При бездіяльності особа не втручається у розвиток причинного зв'язку і тим самим створює реальну можливість настання суспільно небезпечних наслідків. Бездіяльність повинна бути не лише однією 3 необхідних умов, але й причиною наслідку, що настав [18, с.64-65].

Типовим випадком вчинення насильницького злочину через бездіяльність є позбавлення малолітньої дитини іiї матір'ю (безпорадної особи піклувальником) належних умов існування (іжі, тепла тощо), через що настає іï смерть. Психічний вплив також може полягати не лише у дії, а й у бездіяльності. Це, наприклад, жорстоке поводження у вигляді систематичного неповідомлення необхідної потерпілому інформації, яку суб'єкт злочину зобов'язаний повідомити, що призвело до самогубства потерпілого [19, с.35].
Виходячи $з$ принципу законності, насильницьке діяння, як форма злочинної поведінки, повинне відповідати ознакам злочину, передбаченим у ч.1 ст.11 КК України, тобто бути суспільно небезпечним, винним і передбаченим КК України.

Що стосується суспільної небезпеки насильства, здається цілком обгрунтованим підхід А.Є. Жалінського, згідно якого, оцінювати небезпеку насильства необхідно як мінімум за двома напрямками: за його змістом, виділяючи конкретні форми, інтенсивність, механізми, та за його наслідками, виявляючи мету, для досягнення якої насильство використовується як спосіб [20, с.112].

Відносно такої ознаки насильства, як способу вчинення злочину, як винність, то, на наш погляд, мова повинна йтися виключно про умисну форму вини.

У зв'язку з цим, ми принципово не можемо погодитися 3 позицією Н.В. ДовганьБочкової, яка питання форми вини при вчиненні насильницьких злочинів зводить до «термінологічної суперечки» що «не має істотного значення для визначення суті насильства» у силу того, що в поняття насильства як способу вчинення злочину не слід закладати певну конкретну форму вини, оскільки це безпідставно суттєво звужує його зміст $[21$, с.130]. На думку вказаного автора, встановлення форми вини насильницького способу вчинення злочину не має принципового значення, «оскільки форма вини, з якою вчиняється злочин обумовлюється законодавцем в диспозиції окремо або випливає з їі змісту. Якщо ж $є$ певні сумніви стосовно форми вини, $з$ яким вчиняється злочин, то цей недолік слід виправляти шляхом законодавчого уточнення диспозиції, а не доктринальним тлумаченням поняття «насильства», зокрема, як способу вчинення злочину» [21, с.131].

Злочинне діяння це, перш за все, це усвідомлений, вольовий акт поведінки людини, спрямований зовні, що формується під впливом певних мотивів та спрямований на досягнення конкретної мети. Спосіб вчинення злочину має як зовнішні (об'єктивні) ознаки, що 
характеризують фізичний операційний процес здійснення злочинного діяння, а саме яким чином, в яких умовах, шляхом використання яких сил та засобів вчинено діяння, так і внутрішніми (суб'єктивними) ознаками, що представляють собою усвідомлений, вольовий акт по застосуванню прийому та сукупності прийомів виконання злочинної дії [22, с.37].

Усвідомлювана спрямованість насильства проти іншої людини всупереч або поза її волі та його специфічна функціональність (спосіб досягнення певної цілі через заподіяння смерті, фізичної та/або психічної травми, обмеження свобод волевиявлення або дій іншої людини або спосіб отримання задоволення через фізичні та/або психічні страждання жертви) обумовлює можливість вчинення насильницьких злочинів лише умисно. Саме наявність умислу на настання зазначених суспільно-небезпечних наслідків або свідоме припущення їх настання $\epsilon$ обставиною за якою відмежовують насильницькі злочини від необережного заподіяння шкоди життю чи здоров'ю іншій людині.

Крім того, спосіб вчинення злочину - це система прийомів, дій, операційних комплексів, зумовлених метою і мотивами дій, психічними і фізичними якостями особистості, в яких виявляються психофізіологічні і характерологічні особливості людини, іiі знання, вміння, навички, звички і ставлення до різних проявів дійсності. Для кожного злочину існує свій системний «набір», комплекс дій і операцій [23, с.105]. Особи, які вчиняють насильницькі злочини, вбачають позитивне значення обраного ними способу вчинення злочину в тому, це найефективніший чи єдино можливий спосіб відстояти свої інтереси у конфліктній ситуації або задовольнити свої потреби, .або вважають безглуздим і негідним використання правомірних способів розв'язання гострих проблемних ситуацій у міжособистісних відносинах [24, с.111]. Таким чином, насильницький спосіб вчинення злочини характеризує не лише об'єктивну сторону злочинного діяння, але й вказує на специфічну спрямованість особистості зло- чинця, який обирає саме такий спосіб реалізації злочинного наміру, що враховується при визначенні суспільної небезпечності кожного окремого злочинного діяння та, відповідно, призначенні покарання. Зазначене враховане законодавцем при конструюванні норм (зокрема визначенні санкцій), що передбачають відповідальність за вчинення насильницьких злочинів.

Як вже зазначалося, насильницьке діяння, як форма злочинної поведінки, повинне бути передбаченим КК України, тобто протиправним. Саме передбачення того чи іншого насильницького діяння КК України дає можливість відмежовувати кримінальне насильство від легітимного насильства (виховного примусу, законного покарання, заподіяння шкоди за обставин, що виключають злочинність діяння тощо) та інших незлочинних деліквентних форм насильства.

Що стосується конкретних можливих шляхів реалізації насильницького способу вчинення злочину, тобто методів, послідовності рухів та прийомів чи сукупності засобів, що використовуються для вчинення злочину, то найбільш типовими формами реалізації насильницького способу (виконання злочинного насильницького діяння) є наступні.

Найбільш розповсюдженим способом вчинення насильницьких злочинів є тілесні ушкодження. Побої не становлять особливого виду ушкоджень та характеризуються заподіянням багаторазових ударів [25]. Мучення (заподіяння мук) - вчинення тривалих за часом і безперервних у своїй змістовній сукупності умисних діянь, що позбавляють потерпілого необхідних природних умов його життєдіяльності (іжі, пиття, тепла тощо), або залишають його в шкідливих для здоров'я умовах тощо, у силу чого заподіюють йому фізичний біль. Мордування - багаторазове та/або тривале спричинення болю: щипання, шмагання, нанесення численних, але невеликих ушкоджень тупими чи гостро колючими предметами, діяння термічних факторів та інші аналогічні дії. Слід зазначити, що на відміну від побоїв, при яких винною особою 
використовуються механічні фактори зовнішнього середовища (дія кінетичної енергії якого-небудь предмета), мучення та мордування може здійснюватися 3 використанням дії фізичних факторів зовнішнього середовища (дія високих чи низьких температур, підвищеного i зниженого барометричного тиску, ушкодження електричним струмом, вплив різними видами променистої енергії, дії тощо). Тортури - насильницькі дії, що мають характер побоїв, мордування або мучення, спосіб вчинення яких характеризується більшою тривалістю у часі та/або витонченим поєднанням зазначених форм фізичного насильства між собою та/або 3 різними формами психічного впливу на потерпілого. Знущзання - цинічне приниженням гідності та ганьблення честі потерпілого. Глумління являє собою найбільш гостру (тяжку) форму знущання, що характеризується виключним цинізмом вчинюваних дій. Також типовими формами реалізації насильницького способу вчинення злочину $\epsilon$ різного роду погрози (вбивством, застосуванням фізичної сили, позбавленням волі, притягненням до кримінальної відповідальності, розповсюдженням різних відомостей, пошкодженням або знищенням майна, підпалом, позбавленням матеріального забезпечення тощо); примус; образа, залякування; наклеп тощо.

3 урахуванням зазначеного, можна визначити наступні ознаки насильства як способу вчинення злочину: 1) це умисний; 2) протиправний; 3) енергетичний (фізичний) та/або інформаційний (психічний) вплив на іншу людину; 4) шляхом дії або через бездіяльність; 5) всупереч або поза волі потерпілого; 6) здатний заподіяти смерть, фізичну та/або психічну травму, а також обмежити свободу волевиявлення або дій людини.

Таким чином під насильством, як способом вчинення злочину слід розуміти умисний, протиправний енергетичний вплив на органи i тканини організму людини, їх фізіологічні функиії, иляхом використання матеріальних факторів зовнішнього середовища (механічних, фізичних, хімічних і біологічних) та/або вплив на ї̈ психіку шляхом інформащійного впливу, шзо вчиняється шляхом дії або через бездіяльність всупереч або поза ї (людини) волі, здатний заподіяти смерть, фізичну та/або психічну травму, а також обмежити свободу волевиявлення або дій людини.

\section{ЛІТЕРАТУРА}

1. Брайнин Я. М. Уголовная ответственность и ее основание в советском уголовном праве / Я. М. Брайнин. - М. : Юрид. лит., 1963. $-275 \mathrm{c}$.

2. Совершенствование мер борьбы с преступностью в условиях научно-технической революции / [И. С. Горелик, П. С. Дагель, О. Л. Дубовик и др. ; отв. ред. В. Н. Кудрявцев]. - М. : Наука, 1980. - 296 с.

3. Панов Н. И. Основные проблемы способа совершения преступления в советском уголовном праве : автореф. дис. на соискание науч. степени д-ра юрид. наук / Н. И. Панов. - Х., 1987. -27 с.

4. Даньшин И. Н. Криминологическое понятие насильственной преступности, ее количественно-качественные показатели и тенденции развития / Даньшин И. Н. // Проблеми боротьби з насильницькою злочинністю в Україні : зб. матеріалів наук.-практ. конф. / ред.: В. І. Борисов ; Нац. юрид. акад. України ім. Я. Мудрого, Харк. Центр вивчення організов. злочинності. - Х. : ПФ «Книжк. вид-во «Лествиця Марії», 2001. - С. 62-64.

5. Бандурка А. М. Вандализм / А. М. Бандурка, А. Ф. Зелинский. - Х. : Ун-т внутр. дел, 1996. -198 с.

6. Берковиц Л. Агрессия: причины, последствия и контроль: Секреты причин насилия, мотивов убийств, гнева, враждебности, ненависти, разрушения, предрасположенности личности к насилию / Л. Берковиц. - Пер. с англ. СПб. : Прайм-ЕВРОЗНАК, 2001. - 510 с.

7. Петин И. А. Механизм преступного насилия / И. А. Петин. - СПб. : Юридический центр Пресс, 2004. - 343 с.

8. Дубинин Н. П. Что такое человек? / Н. П. Дубинин. - М. : Мысль, 1983. - 334 с. 
9. Ігнатов О. Кримінальне насильство: окремі питання / О. Ігнатов // Право України. 2005. - № 3. - С. 67-71.

10. Морфология человека : учеб. пособие для биол. спец. / [В. Г. Властовский, М. С. Войно, Т. Д. Гладкова и др.] ; под ред. Б. А. Никитюка, В. П. Чтецова. - М. : Изд-во МГУ, 1983. - $320 \mathrm{c}$.

11. Судебная медицина : учеб. для вузов / [Л. О. Барсегянц, В. Н. Крюков, А. А. Солохин и др.] ; под общ. ред. В. В. Томилина. М. : ИНФРА-М : Норма, 1996. - 369 с.

12. Шарапов Р. Д. Физическое насилие в уголовном праве / Р. Д. Шарапов. - СПб. : Юридический центр Пресс, 2001. - 297 с.

13. Еникеев М. И. Основы общей и юридической психологии : учеб. для вузов / М. И. Еникеев. - М. : Юристь, 1996. - 630 с.

14. Дубровский Д. И. Информация, сознание, мозг / Д. И. Дубровский. - М. : Высш. школа, 1980. - 286 с.

15. Кондратюк Л. В. Антропология преступления. (Микрокриминология) / Л.В.Кондратюк. - М. : НОРМА, 2001. - $338 \mathrm{c}$.

16. Сердюк Л. В. О понятии насилия в уголовном праве / Л. В. Сердюк // Уголовное право. - 2004. - № 1. - С. 51-52.

17.15. Матвеев Г. К. Теоретические вопросы причинности бездействия / Г. К. Матвеев // Советское государство и право. 1962. - № 10. - С. 57-67.

18. Загородников Н. И. Советское уголовное право. Общая и Особенная части /
Н. И.Загородников. - М. : Юридическая литература, $1975 .-568 \mathrm{c}$.

19. Гуртовенко О. Л. Психічне насильство у кримінальному праві України: дис. ... кандидата юрид. наук : 12.00.08 / Гуртовенко Олег Леонтійович. - Одеса, 2008. - 251 с.

20. Жалинский А. Э. Насильственная преступность и уголовная политика / А. Э. Жалинский // Советское государство и право. 1991. - № 3. - С. 101-112.

21. Довгань-Бочкова Н. В. Спірні питання, що стосуються фізичного насильства як способу вчинення злочину / Н. В. ДовганьБочкова // Форум права. - 2010. - № 2. С. 129-137 [Електронний ресурс]. - Режим доступу: http://www.nbuv.gov.ua/ejournals/ FP/2010-2/10dnvcvz.pdf.

22. Панов Н. И. Способ совершения преступления и уголовная ответственность / Н. И. Панов. - Харьков : Вища шк. : Изд-во при Харьк. ун-те, 1982. - 161 с.

23. Еникеев М. И. Юридическая психология : учебник для вузов. - М. : Изд. группа НОРМА-ИНФРА, 2001. - 517 с.

24. Прикладная юридическая психология : учеб. пособие для вузов / под ред. А. М. Столяренко. - М. : ЮНИТИ-ДАНА, 2001. - 639 с.

25. Наказ Міністерства охорони здоров'я України «Правила судово-медичного визначення ступеня тяжкості тілесних ушкоджень» : від 17.01.1995 р., № 6 [Електронний pecypc]. - Режим доступу: http://zakon.rada. gov.ua/cgi-bin/laws/main.cgi?nreg=z0255-95.

Ігнатов О. М. Насильство як спосіб вчинення злочину: поняття та сутність / О. М. Ігнатов // Форум права. - 2010. - № 3. - С. 144-151 [Електронний ресурс]. - Режсим доступy: http://www.nbuv.gov.ua/e-journals/FP/2010-3/10iomptc.pdf

В рамках дослідження сутності насильства з кримінально-правової точки зору надане визначення насильства та встановлені його ознаки як способу вчинення злочину. $* * *$

Игнатов А.Н. Насилие как способ совериения преступления: понятие и сущность В рамках исследования сущности насилия с уголовно-правовой точки зрения дано определение насилия и установлены его признаки как способа совершения преступления. $* * *$

Ignatov A.N. Violence as a Method of Feasance of Crime: Concept and Essence Within the limits of research of essence of violence from the criminally-legal point of view definition of violence is made and its signs as way of commission of crime are established. 